\section{文献}

KoBAyASHI, T. (1953): Geology of South Korea with special reference to the limestone plateau of Kogendo. Jour. Fac. Sci. Univ. Tokyo, Sec. 2, 8, 145293.

Kobyashi, T. (1967): The CombroOrdovician formations and faunas of South Korea. Part X, Section C. The Cambrian of Eastern Asia and other areas of the continent. Jour. Fac. Sci. Univ. Tokyo. Sec. 2, 16, 381-535.

小林貞一 (1977) : 朝鮮地史の今昔, その 2 .
地学雑誌, 86, 191-207.

LEE, J. H., LEE, H. Y., YU, K. M. and LEE, B. S. (1989): Discovery of microfossils from limestone pebbles of the Hwang-gangri Formation and their stratigraphic significance. Jour. Geol. Soc. Korea, 25, 1-15.

ReEdman, A. J. and UM, S. H. (1975): Geology of Korea. Geological and Mineral Institute of Korea, 139p.

YANAI, S., PARK, B. S. and OTOH, S. (1985): The Honam shear zone: deformation and tectonic implication in the Far East. Sci. Pap. Coll. Arts and Sci., Univ. Tokyo, 35, 185-210.

日本海東縁海岸地域の完新世地震性地殼変動

$$
\text { 宮内崇 裕* }
$$

\title{
Holocene Coastal Seismotectonics in the Eastern Margin of the Sea of Japan
}

Takahiro MIYAUCHI*

\section{I. はじめに}

東北日本内弧では歷史時代に土地の昇降を伴ら プレート内地震 $(\geqq \mathrm{M} 6)$ が発生し, 逆断層運動 に伴う変動地形が数多く知られている。更新世後 期の隆起速度が大きい( $>1.0 \mathrm{~m} / 10^{3}$ 年) 日本海 東縁地域 (半島部や離島) には, 歴史地震によっ て離水した波食棚と更新世段丘との間に複数の海 成段丘が認められることがある。これらは高度 $10 \mathrm{~m}$ 以下に小さな比高をもって出現し, 完新世 に離水したと推定される。このことは地震活動の 歴史が離水地形に記録されている可能性を示す。 地震の規模 - 頻度 - 周期や 1 回の大地震に伴了地 款変動の “くせ”を明らかにしていくために，こ 孔らの完新世海成段丘の高度と年代, 現成波食棚 の発達状況などについて広域に調査を行なった。

\section{II. 完新世海成段丘の高度と年代}

各地に和いて掘削調查を併用することによって 年代測定試料の採取に努めたが，段丘堆積物中よ
り直接試料を得ることはできなかった。男鹿半島 西岸飞扔いて離佂岩の離水汀線付近 (高度 $0.7 \mathrm{~m}$ ) から唯一貝化石 (マガキ, へビガイ, ヤッコカン ザシ）を採取し，マガキより770土70年（A. D. 1180)の ${ }^{14} \mathrm{C}$ 年代測を得た。この汀線の高度は 1939 年 (昭和 14 年) の男鹿地震時の隆起量 (今 村, 1941 ; 今泉, 1977) にほぼー致している。

最高位の完新世海成段丘の旧汀線高度は半島部 や離島で高くなるが，高度 $10 \mathrm{~m}$ を超えることは 汪とんどない（図 1)。段丘の形成年代の推定資 料として ${ }^{14} \mathrm{C}$ 年代が得られているのは，奥尻島 $(3,950$ 年前 : 三好渒か，1985), 西津軽海岸 $(5,590$ 年前: 八木・吉川, 1988), 男鹿半島北東部 $(6,320$ 年， 4,560 年前: 白石，1982）であり，いずれも 後水期海進のピーク以後に離水したと考兄られて いる。

段丘の数は最高 4 つ(図 1 : 男鹿半島, 粟島), 現成の波食棚がよく発達するのは, 寿都, 松前, 飛島である。波食棚の幅は数 $10 \sim 100 \mathrm{~m}$ 注どであ るが，飛島では $200 \mathrm{~m}$ 近い所もある。

\footnotetext{
* 千葉大学理学部地学教室 * Department of Earth Sciences, Chiba University
} 


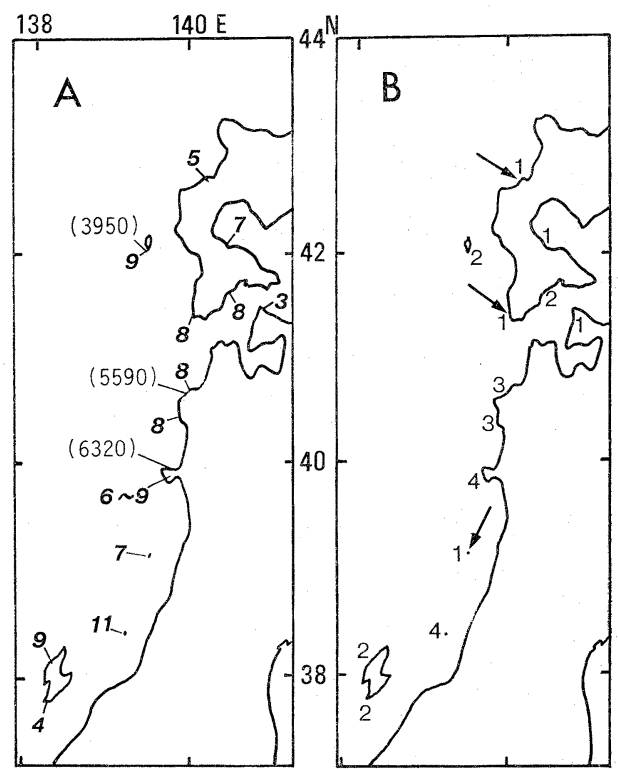

図 1 完新世海成段丘に関するデータ

$\mathrm{A}$ : 最高位の完新世海成段丘の旧汀線高度 $(\mathrm{m})$

（）内の数值は ${ }^{14} \mathrm{C}$ 年代を示す。

$\mathrm{B}$ : 完新世海成段丘（あるいは異なるレベルに ある旧汀線) の数

矢印は現成波食棚の発達の良い地域を示す。

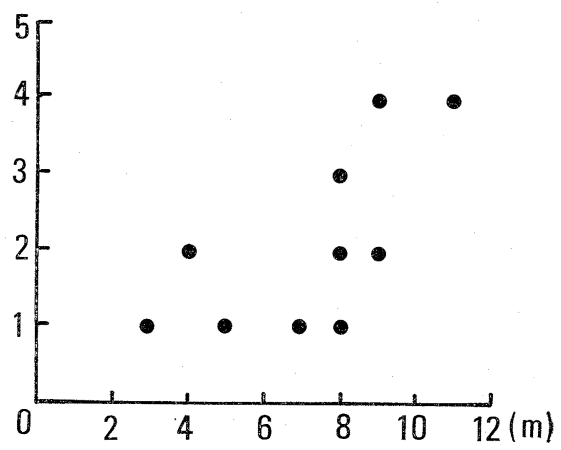

図 2 最高位の完新世旧汀線高度と旧汀 線の数の関係

縦軸：旧汀線の数

横軸：各地域の旧汀線高度最高值

\section{III. 完新世の地震活動}

海成段丘の年代資料は十分ではないが，地震活 動に伴ら隆起イベントを次のように考えてみるこ とができる。最高位の旧汀線高度は段丘の数と正 の相関があるよらにみ光るが，実際にはばらつく (図 2)。とくに旧汀線高度の幅を $7 \sim 9 \mathrm{~m}$ にと れば，段丘の数は $1 \sim 4$ と変化する。これは，段 丘の数の多い地域は海面変化以外にェピソディッ クな隆起を何回か経験してきた可能性を示してい る。

最高位の旧汀線高度が $8 \mathrm{~m}$ 前後でありながら 段丘の数が少ない地域（松前, 飛島）は, 地震の 発生間隔が他地域と大きく変わらないとすれば， 近い将来隆起を蒙るよらな地震を経験するのかも 知れない。また隆起をもたらした最後の地震から の時間に比例して波食棚が広く発達すると考えれ ば，この 2 地域の現成波食棚が広いことは他地域 に比べ地震の発生が近いことを推定させる。北緯 $41.5^{\circ} \sim 43^{\circ}$ の地帯（渡島半島の主部）甭史時 代に大地震の空白域であることは，松前付近を隆 起させる地震が起きそらなことと因果関係があり そうである。

本地域では貝化石などによる ${ }^{14} \mathrm{C}$ 年代測定資 料の採取はあまり期待でさないことがわかり，当 初の目的を達成するためにも別の年代測定法を導 大していかなければならない。

\section{文献}

今泉俊文 (1977)：男鹿半島の地殼変動と地 震. 東北地理, 29, 35-44.

今村明恒 (1941)：昭和14 年の男鹿地震に伴 へる陸地変形。地震，13，207-215.

三好真澄・太田陽子・澤 祥・今泉俊文・鹿 島 熹 (1985)：北海道奥尻島の完新世 海成段丘。地理評，58A，596-608.

白石建雄 (1982)：秋田県男鹿半島に沶ける 完新世段丘（橋本段丘）堆積物中の木片お よび釜谷地層中の貝殼の ${ }^{14} \mathrm{C}$ 年代一一日 本の第四紀層の ${ }^{14} \mathrm{C}$ 年代 (141) - - . 地 球科学, 36, 51-54.

八木浩司・吉川契子(1988)：西津軽沿岸の完 新世海成段丘と地款変動. 東北地理, 40 , 247-257. 